\title{
Surface water quality of small rivers in the Ukrainian regions of right-bank Polissia
}

\author{
Igor Gopchak ${ }^{1}$, Tetiana Basiuk ${ }^{2}$, Artem Yatsyk ${ }^{1}$, and Oksana Yaromenko ${ }^{2}$ \\ ${ }^{1}$ National University of Water and Environmental Engineering, Rivne, Ukraine \\ ${ }^{2}$ International University of Economics and Humanities Academician Stepan Demianchuk, Rivne, Ukraine
}

\begin{abstract}
The quality of surface waters of small rivers of the Ukrainian regions of right-bank Polissia, belonging to the basin of the river Pripyat, was estimated. The study was conducted via systematic observations based on the ecological classification of surface water quality of land and estuaries of Ukraine, which includes a set of hydrophysical, hydrochemical, hydrobiological and other indicators, which were grouped into three blocks of indicators: salt composition of water; tropho-saprobiological (ecologicalsanitary) block; specific substances of toxic action. The integrated (ecological) index was determined, by which the class and category of surface water quality were established. The results of observations on the quality of surface waters of the rivers of the Ukrainian regions of right-bank Polissia indicate their satisfactory condition. Surface waters, on average, correspond to the II class of water quality, and the worst - to the III class. Water protection measures have been proposed to improve the ecological condition of small river basins in specified region.
\end{abstract}

\section{Introduction}

Deteriorating ecological conditions of river systems in Ukraine, as a result of irrational use of water resources and technogenic impact, are an ever-present problem, a problem for present and future generations. The main sources of pollution of river basins are industrial and municipal waste waters, agricultural runoff, surface runoff and atmospheric precipitation $[1 ; 2]$.

The growing anthropogenic impact on the environment, its pollution by industrial waste, leads a significant deterioration of the ecological conditions of all riplatter, the most vulnerable being small rivers, which are used primarily for communal, agricultural purposes and industrial purposes, while also being points of wastewater discharge. This leads to continuous deterioration of natural environment, especially that of river basins, as they undergo constant changes. This is primarily due to their intensive, irrational use. The quality of surface waters in both large and small rivers depends on the degree of their contamination by industrial waste and utilities, as well as surface runoff from settlements, industrial facilities, agricultural lands, etc. After all, small rivers create the preconditions for the zonal regularity of the formation of water resources of large rivers. Thus, the problem of pollution of small rivers and their hydroecological analysis are quite relevant today [3; 4].

The urgency of assessing the surface water quality of small rivers in the Ukrainian regions of right-bank Polissia stems from the high anthropogenic (industrial and agricultural) load on these ecosystems and continuous deterioration of surface waters quality there. In the basins of small rivers, the resilience of natural landscapes has decreased, and in most cases there is an ongoing decline of water quality from class I to class III. The current regulatory framework is not able to stop these processes; furthermore, when compared with similar regulatory framework of advanced European countries, it can be considered obsolete. In this regard, there is an urgent need to develop a new regulatory framework and, above all, to conduct immediate environmental assessment and establish new environmental standards for water quality of rivers belonging to the Ukrainian regions of right-bank Polissia. Creation of new framework will concentrate efforts of all subjects related to water management on development and implementation of new environmental measures addressing ecological status of rivers in the regions, while also establishing new scientifically based indicators of surface water quality, representative of river's natural state $[5 ; 6]$.

Monitoring environmental conditions of surface waters is one of the key tasks of the state's environmental activities, calling for joint efforts and resources of neighboring states, aiming to preserve, rationalize use of surface waters, as well as facilitate mutual "integration" of national and international laws, standards, and allow for continuous international environmental cooperation. Therefore, it is necessary to conduct timely observations of the qualitative condition of the surface water of the river basins and to analyze and summarize information about the condition of water bodies and predict its changes [2; 7-9].

The purpose of this paper is to give assessment of the 
surface water quality of small rivers of the Ukrainian regions of right-bank Polissia (Vyzhivka, Turiya, Tsyr, Stokhid, Styr, Lypa, Prudnyk, Serna, Chornoguzka, Horyn, Putylivka, Sluch, Ubort, Uzh, Noryn).

\section{Methods}

The evaluation of ecological condition of water quality of rivers belonging to the Ukrainian regions of right-bank Polissia was carried out according to the «Methodology of ecological assessment of surface water quality by relevant categories» [10], that allows to compare water quality in individual bodies of water and in bodies of water situated of different regions, on the basis of uniform ecological criteria. It includes three blocks of indicators: block of salt composition $\left(\mathrm{I}_{1}\right)$, block of trophosaprobiological (ecological-sanitary) indicators $\left(\mathrm{I}_{2}\right)$, block of indicators for specific toxic substances $\left(\mathrm{I}_{3}\right)$. Block indicators for salt composition $\left(\mathrm{I}_{1}\right)$ includes chlorides, sulfates, mineralization value. Block of trophic and saprobiological (ecological and sanitary) indicators $\left(\mathrm{I}_{2}\right)$ includes: suspended matter, nitrates, nitrites, ammonium nitrogen, phosphates, dissolved oxygen, hydrogen index - $\mathrm{pH}$, chemical oxygen consumption, biochemical oxygen consumption for 5 days. Block of indicators of content of specific toxic substances $\left(\mathrm{I}_{3}\right)$, which has one (general iron) to eight components (general iron, copper, zinc, manganese, total chromium, phenols, petroleum products, synthetic surface active substances).

The average values for the three block water quality indices are determined by calculating the average number of categories for all indicators of specific block, the three worst values for the block are determined by the relatively worst indicator among all indicators of this block. The results of the environmental assessment are presented in the form of a combined value, which is based on the final figures in the three blocks. Conducting a combined water quality assessment for a particular water body as a whole, or for its individual parts, is a prerequisite to determine an integrated environmental index $\left(\mathrm{I}_{\mathrm{E}}\right)$ of said body.

An integral (ecological) index $\left(\mathrm{I}_{\mathrm{E}}\right)$ is calculated using values of block indices to determine the class and water quality category. The procedure for determining the categories of water quality according to the ecological classification for each hydrochemical indicator by average values allowed the absolute quantitative values to be converted into unified, integral indicators of water quality (indices, categories, subcategories, classes), which reflect the essence of the process. This one the changes in the conditions for the formation of water quality under the influence of anthropogenic factors were fixed by the indices, and were defined boundaries of fluctuations of ecological indices of water objects which have important for the decision of issues of water management, implemetation of environmental protection and restoration measures (Fig. 1).

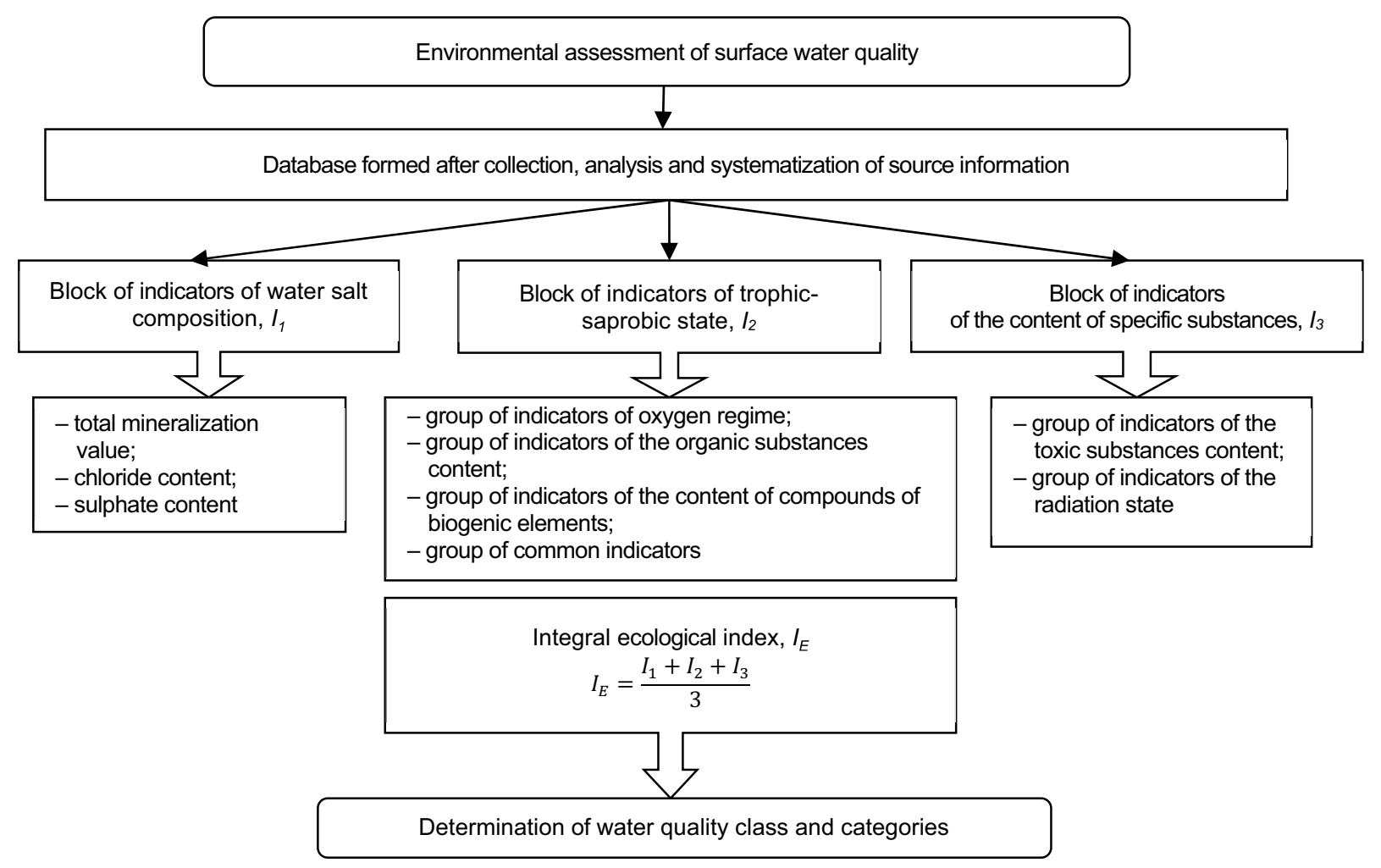

Fig. 1. Flowchart of the environmental assessment of the surface of small rivers belonging to the Ukrainian regions of right-bank Polissia.

The condition of small rivers belonging to the Ukrainian regions of right-bank Polissia was studied by us during 20-year period, from 1999 to 2019. Resulting materials include statistical and cartographic data on the ecological condition, use of land and water resources in small river basins. 
Assessment of water quality by salt composition $\left(\mathrm{I}_{1}\right)$ in selected sections of rivers of the studied basins included evaluation of river water quality by examination of their levels of mineralization, chlorides, sulfates and determination of ionic composition of river waters. For this purpose, according to «Methodology...» [10], a list of the following classifications was used: classification of surface water quality according to mineralization criteria, surface water quality classification according to ionic composition criteria, fresh hypo- and oligogaline water quality classification according to salt composition pollution criteria.

Assessment of water quality of the trophosaprobiological block $\left(\mathrm{I}_{2}\right)$ was conducted using hydrophysical, hydrochemical parameters and saprobity indices. The end result of the assessment is the determination of trophic and saprobity zones of waters according to the ecological classification of surface water quality according to tropho-saprobiological criteria [10].

In «Methodology...» [10] when testing the water for specific toxic substances, the quantitative characteristics of 10 metals, as well as fluorides, cyanides, petroleum products, volatile phenols and synthetic surfactants, a total of 18 elements was screened for. However, the available information does not allow to give a sufficiently objective evaluation of the water quality of the Ukrainian regions of right-bank Polissia according to the criteria for toxic substances. Therefore, the following materials should be considered as indicative, and need further supplementation and clarification.

Calculated values of integral ecological indices $\left(\mathrm{I}_{\mathrm{E}}\right)$ were compared against the environmental classification, with qualitative condition of water and the class and category of its quality being determined. In general, water quality is divided into five classes, which are accepted in many European countries. These classes have certain characteristics and a corresponding colour of the designation, which allows to clearly illustrate the ecological condition of the reservoir (table 1).

Table 1. Classes and categories of surface water quality according to the ecological classification [13].

\begin{tabular}{|c|c|c|c|c|c|c|c|c|}
\hline \multicolumn{2}{|c|}{ Value of indicator $I_{E}$} & $1.0-1.50$ & $1.51-2.50$ & $2.51-3.50$ & $3.51-4.50$ & $4.51-5.50$ & $5.51-6.50$ & $6.51-7.00$ \\
\hline \multirow{4}{*}{$\begin{array}{l}\text { Water quality } \\
\text { classes and } \\
\text { categories by their } \\
\text { natural condition }\end{array}$} & \multirow{2}{*}{ class } & $\mathrm{I}$ & \multicolumn{2}{|c|}{ II } & \multicolumn{2}{|c|}{ III } & IV & $\mathrm{V}$ \\
\hline & & excellent & \multicolumn{2}{|c|}{ good } & \multicolumn{2}{|c|}{ satisfactory } & bad & very bad \\
\hline & \multirow{2}{*}{ category } & 1 & 2 & 3 & 4 & 5 & 6 & 7 \\
\hline & & excellent & very good & good & satisfactory & mediocre & bad & very bad \\
\hline \multirow{4}{*}{$\begin{array}{l}\text { Classes and } \\
\text { categories of water } \\
\text { quality by the } \\
\text { degree of its } \\
\text { cleanness } \\
\text { (pollution) }\end{array}$} & \multirow{2}{*}{ class } & I & \multicolumn{2}{|c|}{ II } & \multicolumn{2}{|c|}{ III } & IV & $\mathrm{V}$ \\
\hline & & very clean & \multicolumn{2}{|c|}{ clean } & \multicolumn{2}{|c|}{ polluted } & dirty & very dirty \\
\hline & & 1 & 2 & 3 & 4 & 5 & 6 & 7 \\
\hline & category & very clean & clean & $\begin{array}{l}\text { fairly } \\
\text { clean }\end{array}$ & slightly polluted & $\begin{array}{l}\text { moderately } \\
\text { polluted }\end{array}$ & dirty & very dirty \\
\hline
\end{tabular}

\section{Results}

Rivers, together with their catchment areas, are complex interconnected systems. Any changes in the catchment area will inevitably lead to change in the river itself. As a result, all the main factors influencing catchment area of a small river (forest cover, wetlands area, humidity, percentage of arable land, presence of pollution, reclamation works, etc.) make it possible not only to evaluate the state of its ecosystem, but also to predict major trends in its development and determine the set of necessary measures that can improve water quality, environmental conditions of rivers and the state of coastal areas. Significant factors influencing small rivers are: presence of municipal, industrial and agricultural runoff. Their impact is rather dangerous, as in some cases the volume of runoff may be the same or even greater than that of a small river $[9 ; 11]$.

The main ecological problems of small rivers of the Ukrainian regions of right-bank Polissia are: inflow of pollutants into rivers from the territories of settlements, industrial facilities and agricultural lands; soil erosion in the catchment areas; discharge of untreated and insufficiently treated wastewater into water bodies [3; 12].

Water quality assessment by indicators of salt composition $\left(I_{1}\right)$. The formation of the chemical composition of the riverbeds of the rivers of the Ukrainian regions of right-bank Polissia takes place in conditions of excessive moisture, prevalence of carbonate-enriched Upper Cretaceous rocks and groundwater present in them, draining into riverbeds. This predetermines the hydrocarbonate-calcium composition of their waters: the relative concentration of $\mathrm{HCO}_{3}{ }^{-}$varies between $27-40 \%$ eq., And $\mathrm{Ca}^{2+}-33-45 \%$ eq.

The salt composition of the water of small rivers of the Ukrainian regions of right-bank Polissia is formed in conditions of high humidity and presence of carbonate and gypsum rocks that form the basis of the catchment area. Therefore, the water of most rivers under natural conditions corresponds, according to the classification of O.O. Alokin, to hydrocarbonate class, calcium group oftype II-III, $\mathrm{C}^{\mathrm{Ca}}{ }_{\mathrm{II}-\mathrm{III}}$.

The waters of the right tributaries of the Pripyat have an average mineralization (in the amount of ions) of 156$350 \mathrm{mg} / \mathrm{dm} 3$. In the waters of the main riverbed of the Pripyat and its tributaries, the content of chlorides is up to $30 \mathrm{mg} / \mathrm{m}^{3}$, sulfates - up to $50 \mathrm{mg} / \mathrm{dm}^{3}$. On average, the waters of most rivers have low $\left(200 \mathrm{mg} / \mathrm{dm}^{3}\right)$ and moderate mineralization $\left(200-500 \mathrm{mg} / \mathrm{dm}^{3}\right)$. The increase in the amount of ions was observed only in places of discharge of insufficiently treated and untreated 
wastewater from municipal, industrial and agricultural facilities (Turiya, Kovel 424 and $514 \mathrm{mg} / \mathrm{dm}^{3}$; Styr, Lutsk 400 and $480 \mathrm{mg} / \mathrm{dm}^{3}$; Horyn River, below the discharge of WTP«Prolisok» 410-440 mg/dm ${ }^{3}$; Ustya River, Rivne $702 \mathrm{mg} / \mathrm{dm}^{3}$; Ubort River, Yemilchyne urban-type settlement $510 \mathrm{mg} / \mathrm{dm}^{3}$ ).

On average, the water of the of small rivers of the Ukrainian regions of right-bank Polissia in terms of average and worst values of the sum of ions, belongs to category 1 "excellent" in class, "very clean" in degree of purity. It should be noted, that in areas where the highest values of the worst values of mineral content of water belong to category 2, which is caused by the anthropogenic activity.

The content of chlorides and sulfates depends on the natural conditions under which the chemical composition of water forms, as well as on the degree of intensity of anthropogenic activity in the catchment area. On average, in the Pripyat basin, the chlorides levels range from category 1 «excellent», "very clean», starting at the sources, to category 3 -«good», «fairly clean» in the middle reaches. With the exception of the waters of the rivers Ubort (Yemilchyne) and Noryn' (Ovruch), with average and worst chlorine ion content (97.2-143.0 and
$79.8-104.5 \mathrm{mg} / \mathrm{dm}^{3}$, respectively) classified as category 4 («satisfactory», «slightly polluted» waters), which is caused by the discharge of insufficiently treated wastewater from municipal enterprises of the urban-type settlement of Yemilchyne and city of Ovruch.

As for sulfates, according to the average and worst values of this indicator, the waters of the rivers of the Ukrainian regions of right-bank Polissia are in between 1 and 2 quality categories and varies from «excellent», «very clean» to «very good», «clean».

Evaluation of situation in the water bodies of the Ukrainian regions of right-bank Polissia by the criteria of pollution by components of the salt composition indicates that situation is quite good. The calculated indices of salt composition $\left(I_{I}\right)$ indicate that the water of the main riverbed of the Pripyat on the average and worst values of $\mathrm{I}_{1}$ is characterized as «excellent», «very clean» $\left(1,0 \leq \mathrm{I}_{1} \leq 1,3\right)$, «very good», «clean» water $\left(1,7 \leq \mathrm{I}_{1} \leq 2,0\right)$. There is only some deterioration in the water quality of the Ubort and Noryn' rivers, where the indices are in the 1,7-3,0 and 2,0-2,7 ranges respectively. That is, water quality varies from «very good», «clean» to «good», «fairly clean» (table 2).

Table 2. Water quality assessment of small rivers of the Ukrainian regions of right-bank Polissia according to the worst and average values of block indices $\left(I_{1}, I_{2}, I_{3}\right)$

\begin{tabular}{|c|c|c|c|c|c|c|c|}
\hline \multirow{3}{*}{ № } & \multirow{3}{*}{ River* } & \multicolumn{6}{|c|}{ The value of indices } \\
\hline & & \multicolumn{2}{|c|}{$\mathrm{I}_{1}$} & \multicolumn{2}{|c|}{$\mathrm{I}_{2}$} & \multicolumn{2}{|c|}{$\mathrm{I}_{3}$} \\
\hline & & avg. & $\max$. & avg. & $\max$. & avg. & $\max$. \\
\hline 1 & Pripyat & 1,0 & 1,3 & 4,6 & 5,3 & 3,5 & 4,5 \\
\hline 2 & Vyzhivka & 1,0 & 1,7 & 4,8 & 5,5 & 3,4 & 4,6 \\
\hline 3 & Turiya & 1,0 & 1,3 & 4,8 & 5,2 & 3,9 & 5,0 \\
\hline 4 & Tsyr & 1,7 & 1,7 & 4,8 & 5,3 & 3,3 & 4,6 \\
\hline 5 & Stokhid & 1,3 & 1,3 & 4,1 & 4,9 & 3,0 & 4,7 \\
\hline 6 & Styr & 1,3 & 1,3 & 4,7 & 5,2 & 3,9 & 5,0 \\
\hline 7 & Lypa & 1,3 & 1,7 & 4,6 & 4,9 & 2,2 & 3,5 \\
\hline 8 & Prudnyk & 1,0 & 1,0 & 4,9 & 5,2 & 3,5 & 4,8 \\
\hline 9 & Serna & 1,0 & 1,0 & 3,8 & 3,9 & 2,2 & 3,0 \\
\hline 10 & Chornoguzka & 1,3 & 1,3 & 4,0 & 4,0 & 2,1 & 2,5 \\
\hline 11 & Horyn & 1,3 & 1,3 & 4,6 & 4,8 & 2,2 & 3,9 \\
\hline 12 & Putylivka & 1,3 & 1,7 & 4,4 & 4,9 & 2,7 & 3,6 \\
\hline 13 & Sluch & 1,3 & 1,7 & 4,1 & 4,7 & 3,3 & 3,4 \\
\hline 14 & Ubort & 2,0 & 2,3 & 4,4 & 4,8 & - & - \\
\hline 15 & Uzh & 1,7 & 2,0 & 3,7 & 4,3 & 4,6 & 5,0 \\
\hline 17 & Noryn & 2,0 & 2,7 & 4,8 & 5,0 & 3,0 & 3,2 \\
\hline \multicolumn{2}{|c|}{ On average in the river basin } & 1,3 & 2,0 & 4,4 & 4,8 & 3,1 & 4,1 \\
\hline
\end{tabular}

Note: * - on average along the river. $\mathrm{I}_{1}$ - block index of salt composition; $\mathrm{I}_{2}$ - block tropho-saprobiological index; $\mathrm{I}_{3}-$ block index of specific toxic substances; $\mathrm{I}_{\mathrm{E}}$ - ecological water quality index.

Water quality assessment by tropho-saprobiological (sanitary and hygienic) indicators $\left(I_{2}\right)$. The water quality of small rivers of the Ukrainian regions of right-bank Polissia, assessed by the worst values of trophosaprobiological indicators, belonged to category 5, subcategory 5(6), i.e. eupolytrophic waters with slant to polytrophic waters of á-mesosaprobic and á"mesosaprobic zones. The water quality evaluated by the average values of the same indicators, belonged to subcategory 4-5, i.e. in the transitional state from eutrophic to eupolytrophicwaters of the transitional $\beta^{\prime \prime}-$ mesosaprobic to ' $\alpha$-mesosaprobic zone.

The waters of small rivers of the Ukrainian regions of right-bank Polissia as a whole are also assigned quality category 5 «mediocre», «moderately polluted», but if they are evaluated by the worst values of the indicators they would unconditionally belong to the eupolytrophic waters of the a'-mesosaprobic zone, while judging by the average values of these indicators - to the eupolytrophic waters with a slope to eutrophic waters of the $\alpha^{\prime}$-mesosaprobic 
zone with a slant to $\beta "$-mesosaprobic zone. That is, within the 5 th category of water quality, these rivers vary only by some differences in the worst and average values, expressed at the subcategory level.

Overall, the water quality in the rivers of small rivers of the Ukrainian regions of right-bank Polissia, assessed according to tropho-saprobiological criteria, corresponds to class III («satisfactory», «polluted»). The main reason for the current state of the rivers is the excessive content of nitrogen and phosphorus compounds in the water, i.e. intensive eutrophication (table 2).

Water quality assessment by indicators of specific toxic substances $\left(I_{3}\right)$. The index of specific toxic substances $\left(\mathrm{I}_{3}\right)$ indicate a considerably high levels of pollution of the waters of the rivers of small rivers of the Ukrainian regions of right-bank Polissia by specific toxic substances. The value of $\mathrm{I}_{3}$ for the Pripyat River varies in the range of 4,4-5,2 by its worst value («satisfactory», «slightly polluted», - «mediocre», «moderately polluted» water), and the average - 3, 1-3.7 («good», «fairly clean» - «satisfactory», «slightly polluted»). According to the worst values of this index, the water of the Pripyat basin corresponds to the III class of quality «satisfactory», «polluted», and according to the average - II-III class and is assessed as «good», «fairly clean» - «satisfactory», «slightly polluted».

The waters of the rivers Vyzhivka, Turiya, Tsyr,Stokhid, Styr, Prudnyk, Uzh have the highest average and worst values of $\mathrm{I}_{3}$ : the worst values $\left(\mathrm{I}_{3}=4,6\right.$ 5,0 , category 5 , subcategories $4-5$ and 5) is graded as «mediocre», «moderately polluted», class III quality «satisfactory», «polluted» water, and its average value $\left(\mathrm{I}_{3}\right.$ $=3,0-3,9$, categories 3 and 4$)$ as «good», «fairly clean» «satisfactory», «slightly polluted», II-III class «good», «clean» - «satisfactory», «polluted» (table 2).

The rivers Horyn and Putylivka have the same characteristics (average values $\mathrm{I}_{3}=2,2-2,7$, the worst values $\left.I_{3}=3,6-3,9\right)$. The water quality of these rivers corresponds to 2 and 3 categories, subcategories 2 and 3(2) with average values of $\mathrm{I}_{3}$ and 4th category, and subcategories 3-4 and 4, by the worst, II and III quality class, «good», «clean» and «satisfactory», «polluted».

The waters of the rivers Sluch, Noryn' (Ovruch) and Ubort (Perga) are in the categories«good», «fairly clean» (category 3) and «satisfactory», «slightly polluted» (category 4), and by class quality-«good», «clean» (class II) and «good-satisfactory», «clean-polluted» (class IIIII).

The waters of Chornohuzka and Serna $\left(\mathrm{I}_{3 \mathrm{avg}}=2,1\right.$ and 2,2 , category $2, I_{3 \mathrm{w}}=2,5$ and 3,0 , category 3 , respectively) are graded (by the value of the index of specific toxic substances) as the cleanst.

At $17 \%$ of the study sites located in the Pripyat basin, the index of specific toxic substances $\left(\mathrm{I}_{3}\right)$ was calculated only by determining the total iron content in river waters. Therefore, it makes no sense to use such insignificant information to calculate the integrated index of specific toxic substances.

Limited data available from field experiments in the block of specific toxic substances made it possible to determine only an approximate grade for water quality. The results displayed a tendency to reduction of anthropogenic impact on water by such compounds as iron and chromium, although the nickel content of water deteriorated from categories 2 and 4 to category 5 by average and the worst indicators. On average, the quality of water in the region has improved, in regards to pollution with specific toxic substances, as according to the average and worst indicators it has «appreciated»from categories 4 and 5 to category 3, quality class II, water «good», «clean».

Integrated environmental assessment of surface water quality $\left(I_{E}\right)$. The essence of determining the joint grade of water quality in the of small rivers of the Ukrainian regions of right-bank Polissia as a whole and at individual observation points is to calculate the integrated ecological index $\left(\mathrm{I}_{\mathrm{E}}\right)$, according to which, an unambiguous assessment of river water quality is performed. It is calculated for the average and worst values of block indices for individual items and on average for rivers (table 3). The analysis of calculations indicates that the values of integrated indices $\left(\mathrm{I}_{\mathrm{E}}\right)$, calculated using average and worst values of block indices are: on the rivers of Pripyat - 3,0/3,7; Turiya - 3,2/3,8; Tsyr- 3,3/3,9; Stokhid - 2,8/3,6; Styr $-3,3 / 3,8$; this classifies the waters of these rivers as intermediate between categories 3 and 4 «fairly clean» and «slightly polluted».

According to the water quality class of the main riverbeds of Pripyat, Turiya, Tsyr, Stokhid, Styr, Horyn, Sluch, Uborta, Noryn are rated as «good», «clean» and «satisfactory», «polluted».

During the study period, the best quality of water from the tributaries of the Pripyat according to the $\mathrm{I}_{\mathrm{E}}$ came from the rivers Chornohuzka $\left(2,5 \leq \mathrm{I}_{\mathrm{E}} \leq 2,6\right)$, Serna $\left(2,3 \leq \mathrm{I}_{\mathrm{E}} \leq 2,6\right)$, Sluch $\left(2,5 \leq \mathrm{I}_{\mathrm{E}} \leq 3,3\right)$, and Pripyat $\left(2,3 \leq \mathrm{I}_{\mathrm{E}} \leq 2,5\right)$, and the worst quality in terms of these indices - rivers Vyzhivka $\left(3,1 \leq \mathrm{I}_{\mathrm{E}} \leq 3,9\right)$, Tsyr $\left(3,1 \leq \mathrm{I}_{\mathrm{E}} \leq 3,9\right)$ and $\operatorname{Uzh}\left(3,7 \leq \mathrm{I}_{\mathrm{E}} \leq 3,9\right)$. The waters of these tributaries belong to the II class according to the average and to the III class - according to the worst characteristics of $\mathrm{I}_{\mathrm{E}}$.

Thus, condition of water bodies in the basin of the Pripyat River has improved according to the worst indicators from class III «satisfactory», «polluted» to class II water «good», «clean».

Proposals that will help improve the ecological condition of water resources: 1) reconstruction of existing and construction of new treatment facilities; 2) termination of untreated effluents discharges into rivers; 3) strict following of current water protection legislation by all water users.

\section{Conclusion}

The results of observations on the quality of surface waters of small rivers of the Ukrainian regions of rightbank Polissia indicate their satisfactory condition. Water corresponds to the II-III class of water quality. Exceeding the MPC (Maximum Allowable Concentration) in the surface waters of small rivers of the Right Bank Polissia was recorded by trophosaprobiological indicators. This is due to the high anthropogenic load in river basins, in particular discharges of insufficiently treated wastewater. 
Table 3. Combined water quality assessment of small rivers of the Ukrainian regions of right-bank Polissia according to the worst and average values of the integrated ecological index ( $\mathrm{IE}$ )

\begin{tabular}{|c|c|c|c|c|c|c|c|}
\hline \multirow{2}{*}{ № } & \multirow{2}{*}{ River* } & \multicolumn{2}{|c|}{ IE } & \multicolumn{2}{|c|}{ Grage by class } & \multicolumn{2}{|c|}{ Degree of purity } \\
\hline & & avg. & $\max$. & avg. & $\max$. & avg. & max. \\
\hline 1 & Pripyat & 3,0 & 3,7 & good & satisfactory & pure & polluted \\
\hline 2 & Vyzhivka & 3,1 & 3,9 & good & satisfactory & pure & polluted \\
\hline 3 & Turiya & 3,2 & 3,8 & good & satisfactory & pure & polluted \\
\hline 4 & Tsyr & 3,3 & 3,9 & good & satisfactory & pure & polluted \\
\hline 5 & Stokhid & 2,8 & 3,6 & good & good -satisfactory & pure & pure - polluted \\
\hline 6 & Styr & 3,3 & 3,8 & good & satisfactory & pure & polluted \\
\hline 7 & Lypa & 2,7 & 3,4 & good & good & pure & pure \\
\hline 8 & Prudnyk & 3,1 & 3,7 & good & satisfactory & pure & polluted \\
\hline 9 & Serna & 2,3 & 2,6 & good & good & pure & pure \\
\hline 10 & Chornoguzka & 2,5 & 2,6 & good & good & pure & pure \\
\hline 11 & Horyn & 2,7 & 3,3 & good & good & pure & pure \\
\hline 12 & Putylivka & 2,8 & 3,4 & good & good & pure & pure \\
\hline 13 & Sluch & 2,9 & 3,3 & good & good & pure & pure \\
\hline 14 & Ubort & 3,2 & 3,5 & good & good -satisfactory & pure & pure - polluted \\
\hline 15 & Uzh & 3,3 & 3,8 & good & satisfactory & pure & polluted \\
\hline 17 & Noryn & 3,3 & 3,6 & good & good -satisfactory & pure & pure - polluted \\
\hline \multicolumn{2}{|c|}{ On average in the river basin } & 3,0 & 3,7 & good & satisfactory & pure & polluted \\
\hline
\end{tabular}

Determining the water quality of small rivers is important for assessing the ecological situation of bodies of water of the Ukrainian regions of right-bank Polissia, and main areas of water protection activities to improve the ecological status of each water body, as well as establishing environmental standards for water quality. Environmental assessment of the river water quality is important for generalizing information on the ecological condition of water bodies, forecasting its changes and developing scientifically based water protection recommendations for approving appropriate management decisions in the field of use, protection and reproduction of water re-sources. All this determines the prospect of further studies on the quality of surface waterof of small rivers of the Ukrainian regions of right-bank Polissia.

\section{References}

1. A. Bielski, Inż-nieria i Ochrona Środowiska. T.15. Nr 2, 119-142 (2012)

2. I. Gopchak, T. Basiuk, I. Bialyk, O. Pinchuk, I. Gerasimov Journal of Water and Land Development. No. 42 (VII-IX) 67-75. (2019). doi: 10.2478/jwld-2019-0046

3. A. Yatsyk, Vodohospodarska ekolohiia, № 4. (Kyiv, 2004), p. 480

4. K. Chmielowski, P. Bugajski, B. Kaczorg, Journal of Water and Land Development. 30 (VII-IX), 35-42 (2016)

5. S. Sovhira, H. Honcharenko, V. Honcharenko, V. Berchak, Metodyka doslidzhennia ekolohichnoho stanu baseiniv malykh richok. (Uman, 2016), p. 288

6. V. Stashuk, V. Mokin, V. Hrebin et al., monohrafiia (Kherson, 2014), p. 320
7. F. Krengel, C. Bernhofer, S. Chalov, V. Efimov, L. Efimova, L. Gorbachova, M. Habel, B. Helm, I. Kruhlov, Y. Nabyvanets, N. Osadcha, V. Osadchyi, T. Pluntke, T. Reeh, P. Terskii, D. Karthe, Journal of the Geographical Society of Berlin. Vol. 149. No. 2 3, 157-172. (2018)

8. M. Zabokrytska, Hidrolohiia, hidrokhimiia i hidroekolohiia. T. 2, 142-147 (2011).

9. S. Snizhko, Otsinka ta prohnozuvannia yakosti pryrodnyk hvod (Kyiv, 2001), p. 264

10. Metodyka ekolohichnoi otsinky yakosti poverkhnevykh vod za vidpovidnymy katehoriiamy. (Kyiv, 1998) p. 28

11. I. Gopchak, T. Basiuk, in Abstracts of the ezhdunarodnoi nauchno-praktycheskoi konferentsyy posviashchennoi 100-letyiu melyoratyvnoho obrazovanyia V Horkakh «Aktualnye nauchnotekhnycheskye y ekolohycheskye problemy melyoratsyy zemel», Horky, 14-15 mart 2019.

12. M. Budz D. Hidrotekhnichni sporudy, hidravlika. Hidrolohiia ta hidroenerhetyka, 5 (18), 10-16 (2002)

13. A. Yatsyk, V. Zhukynskyi, A. Cherniavska, I. Yezlovetska Dosvid vykorystannia «Metodyky ekolohichnoi otsinky yakosti poverkhnevykh vod za vidpovidnymy katehoriiamy» (poiasnennia, zasterezhennia, pryklady), (Kyiv, 2006), p.44 